\title{
Our Multiple Single-step Access Results in Percutaneous Nephrolithotomy
}

\author{
Perkütan Nefrolitotomide Multip S Single-step Akses Sonuçlarımız
}

\author{
(D) Cemal Selçuk İşoğlu1, (1) Yusuf Özlem İlbey² \\ ${ }^{1}$ Hakkari State Hospital, Clinic of Urology, Hakkari, Turkiye \\ 2University of Health Sciences, Izmir Tepecik Training and Research Hospital, Clinic of Urology, İzmir, Turkiye
}

\section{What's known on the subject? and What does the study add?}

In some patients, percutaneous nephrolithotomy (PNL) may require more than one access into the kidney due to stone burden. There is no publication that shows the success and complication rates of multiple access single step PNL. Therefore, despite our limitations, our work is valuable in this respect.

\section{Abstract}

Objective: The aim of this study is to evaluate the success and complication rates of percutaneous nephrolithotomy (PNL) with multiple single step access in patients with staghorn kidney stones.

Materials and Methods: A total of 118 patients with staghorn kidney stones, who underwent PNL in our clinic between 2008 and 2015 , were included in the study. All patients were examined with non-contrast abdominal computed tomography before the operation. Demographic data of patients, operation details, intra- and postoperative complications and additional interventions were evaluated.

Results: The mean age of the patients included in the study was 49.6 years. The mean operative time was 139.4 minutes and the mean fluoroscopy time was 126.9 seconds. Postoperative residual stone was detected in 28\% of the patients. Postoperative fever was observed in 19 patients (16.2\%), and sepsis developed in $3(2.5 \%)$ of them. Additional postoperative procedures were required in 11 patients (9.3\%). No patient was lost due to complications. Operation success and complication rates were compatible with the literature.

Conclusion: For staghorn stones, PNL with multiple single step dilatation technique can be used as an effective and safe method in adult patients. Keywords: Percutaneous nephrolitotomy, Single-step dilatation, Multiple access

Öz

Amaç: Bu çalışmada amacımız, staghorn taşı olan hastalarda yapılan single-step multipl akses perkütan nefrolitotomi sonuçlarımızı değerlendirmektir. Gereç ve Yöntem: Kliniğimizde, 2008-2015 yılları arasında staghorn taşı olup PNL yapılan 118 hasta çalışmaya dahil edildi. Operasyon öncesi tüm hastalar kontrastsız batın bilgisayarlı tomografi ile değerlendirildi. Hastaların demografik verileri, operasyon bilgileri, intra/postoperatif komplikasyonlar ve ek girişim gerekliliği ayrıca incelendi.

Bulgular: Çalışmaya katılan hastaların ortalama yaşı 49,6 yıldı. Ortalama operasyon zamanı 139,4 dakika ve ortalama fluoroskopi süresi 126,9 saniyeydi. Hastaların \%28'inde rezidü taş izlendi. On dokuz hastada $(\% 16,2)$ postoperatif ateş yükseliği, 3 hastada $(\% 2,5)$ sepsis görüldü. On bir hastada $(\% 9,3)$ ek girişim gerekliliği oldu. Hiçbir hasta komplikasyonlar nedeniyle ölmedi. Başarı ve komplikasyon oranlarımız literatür ile uyumluydu. Sonuç: Staghorn taşı olan ve PNL planlanan hastalarda, multipl single-step dilatasyon tekniği güvenle uygulanabilir.

Anahtar Kelimeler: Perkütan nefrolitotomi, Single-step dilatasyon, Multipl akses

Correspondence: Cemal Selçuk işoğlu MD, Hakkari State Hospital, Clinic of Urology, Hakkari, Turkiye E-mail: selcukisoglu@hotmail.com ORCID-ID: orcid.org/0000-0002-9999-3908

Received: 05.05 .2018 Accepted: 04.07.2018

Cite this article as: İşoğlu CS, İlbey YÖ. Our Multiple Single-step Access Results in Percutaneous Nephrolithotomy. J Urol Surg 2019;6(1):7-10.

oCopyright 2019 by the Association of Urological Surgery / Journal of Urological Surgery published by Galenos Publishing House. 


\section{Introduction}

Percutaneous nephrolithotomy (PNL) is known as the standard surgical treatment for large stones with high success and low complication rates (1). Establishment of the nephrostomy tract is one of the most important steps of PNL. A tract dilatation of 25-30 Fr following $6 \mathrm{Fr}$ dilatation in one session was described as the single step dilatation with a view to reduce operative and fluoroscopy times (2). Although, it has been mentioned in large-scale studies that single step dilatation techniques can be used as an alternative dilatation technique (3), there is no information about increased complications associated with this method in PNL patients requiring multiple access. The aim of this study was to retrospectively evaluate the success and complication rates of treatment with multiple access using the single-step technique in patients with staghorn kidney stone.

\section{Materials and Methods}

Records of 1150 patients who underwent PNL between 2008 and 2015 were retrospectively reviewed. Written informed consent was obtained from the patients. Patients younger than 18 years and those having urinary system anomalies were excluded from the study. All patients were examined with non-contrast abdominal computed tomography (CT) before the operation. A total of 118 patients having only staghorn kidney stones were included in the study. The period from the injection of contrast medium to the insertion of the Malecot catheter was recorded as the operative time. The surgery was performed in the prone position. Important data such as fluoroscopy time, number of access and intraoperative complications during the operation were also recorded.

At the end of the surgery, a $14 \mathrm{Fr}$ nephrostomy catheter was placed at one access site in all patients. The incisions were closed primarily at other access sites. Malecot catheter was removed on postoperative day 1-3 and the patients without complications were discharged. Postoperative complications and additional interventions were recorded.

All patients were reevaluated with a non-enhanced CT taken at postoperative $1^{\text {st }}$ month. Determining stone-free status or having fragments $\leq 4 \mathrm{~mm}$ was considered treatment success (4). Stone analysis is not being done routinely in our country.

\section{Results}

Data of 118 patients with a mean age of $49.6 \pm 1.69$ years, who met the study criteria, were reviewed. Of the patients, 76 $(64.4 \%)$ were male and $42(35.6 \%)$ were female. Sixty patients $(50.8 \%)$ were operated on the left kidney and 58 patients (49.2\%) on the right kidney. In 96 of the 118 patients (81.3\%), two accesses were sufficient and in 22 patients (18.7\%), 3 accesses were performed. The mean operative time was $139.4 \pm 5.03$ minutes. The mean fluoroscopy time was $126.9 \pm 6.9$ seconds. Postoperative residual stones were observed in 33 patients (28\%) (Table 1).

Three patients $(2.5 \%)$ received blood transfusion due to intraoperative hemodynamic instability. Except hemorrhage, no other intraoperative complications were observed.

Ten patients (8.5\%) received blood transfusion due to postoperative hemodynamic instability, none of them needed more than 2 units. Fever over $38^{\circ} \mathrm{C}$ was detected in 19 patients $(16.2 \%)$ before discharge (first $24-72$ hours). Three patients $(2.5 \%)$ required intensive care due to sepsis (Table 2). They were followed up in the intensive care unit and discharged without any problem. None of the patients died from operation-related complications.

The patients were also evaluated for additional intervention in the postoperative period. Three patients (2.5\%) were placed

Table 1. Preoperative data of the patients

\begin{tabular}{lll}
\hline & Number of patients (n) & Percent (\%) \\
\hline Average age (years) & $49.6 \pm 1.69$ & - \\
\hline Gender (\%) & & 64.4 \\
\hline Male & 76 & 35.6 \\
Female & 42 & - \\
\hline Operation time (minute) & $139.4 \pm 5.03$ & - \\
\hline Fluoroscopy time (second) & $126.9 \pm 16.9$ & \\
\hline Operation side & & 50.8 \\
\hline Right & 60 & 49.2 \\
Left & 58 & 81.3 \\
\hline Number of access & & 18.7 \\
\hline Two & 96 & 72 \\
Three & 22 &
\end{tabular}

Table 2. Complications during and following percutaneous nephrolithotomy

\begin{tabular}{lll}
\hline & $\begin{array}{l}\text { Number of } \\
\text { patients } \\
(\mathbf{n = 1 1 8 )}\end{array}$ & Percent (\%) \\
\hline Intraoperative transfusion (\%) & 3 & 2.5 \\
\hline Postoperative transfusion (\%) & 10 & 8.5 \\
\hline Postoperative fever (\%) & 19 & 16.2 \\
\hline Sepsis and need for ICU (\%) & 3 & 2.5 \\
\hline Additional interventions & & \\
\hline URS & 8 & 6.7 \\
DJS & 3 & 2.5 \\
\hline
\end{tabular}

ICU: Intensive care unit, URS: Ureterorenoscopy, DJS: Double j stent 
double j stent due to wound site discharge and severe colic pain. Ureterorenoscopy (URS) was performed in 8 patients $(6.7 \%)$ upon detection of ureteral stone at the same side (Table 2).

\section{Discussion}

Since the publication of the first PNL series of Wickham and Kellet (5) in 1981, application of open stone surgery lost popularity and it has practically become an outdated method today. Such a wide-scale application of PNL raised concerns among surgical team regarding exposure to radiation during the procedure. Travis et al. (2) described the single-step dilatation method which is an acute dilatation reaching to 25-30 Fr after $6 \mathrm{Fr}$ dilatation and providing reduced operative time as well as reduced radiation exposure. Amjadi et al. (6) reported that the single-step dilatation method with low radiation exposure can be used in almost all adult patients.

We could not find any study in the literature evaluating the success and complication rates for patients with single step access and required more than one access. We evaluated in this study our success and complication rates regarding the single-step access method performed in our patient group who required two or more access due to staghorn kidney stones.

Success rates during PNL vary between $76 \%$ and $84 \%$, depending on the stone size (7). In this study, our success rate was found to be $72 \%$ which was close to the indicated rates in the literature.

Bleeding during and after PNL was always recognized as an important problem. Although insignificant amount of bleeding requiring no transfusion was not considered a complication for PNL, transfusion requiring bleeding in PNL was reported in large series at a frequency of 0-20\% (1). In our study, blood transfusion was needed in a total of 13 patients (11\%); in 3 patients (2.5\%) intraoperatively and in 10 patients (8.5\%) postoperatively, compatible with the literature.

The rate of bleeding requiring selective angioembolization has been reported to be between $0 \%$ and $1.5 \%$ (1). It has been reported that the presence of staghorn stones in particular was actually a risk factor for bleeding requiring embolization (8). In this study, in patients with staghorn stones, none of our patients required embolization.

It has been reported that post-PNL fever was the most common (22\%) complication (9), and a short-term antibiotic therapy could be sufficient for treatment. In our study, fever was determined in 19 patients (16.2\%) and sepsis developed in 3 of them (2.5\%) in whom intensive care was needed. PostPNL urosepsis was noted as a rare complication with a rate of $0.3-1.1 \%$ (1). The high rate of urosepsis in our study can be explained by the inclusion of patients having only staghorn stones, and urosepsis might be due to infection-induced stones in a significant proportion of these patients, although there is no stone analysis available leakage of urine to some extent is generally considered normal until the healing of the tract following withdrawal of the nephrostomy tube. Intervention may be required if leakage continues in the long term in the presence of blood clots or stones in the ureter and associated obstruction.

Post-PNL fistula has been reported to occur in 1.5\%-3\% of patients. Due to prolonged drainage after PNL, double j stent was placed in 3 patients, and due to stones causing ureteral obstruction, URS was performed and double J stent was implanted in 8 patients (6.7\%) (10). In our study, the rate of additional interventions after PNL was determined to be higher with respect to the literature, and this was correlated with initially high stone burden.

Our study is not a comparative study. Thus, we cannot mention about the advantages of multiple single step dilatation comparatively in terms of operative time and radiation exposure. Nevertheless, this technique has been reported to shorten the operative time and reduce radiation exposure (11).

\section{Study Limitations}

The retrospective design of the study and the absence of comparative design are the main limitations of our study. Moreover, the rate of infection-induced stones which may explain the higher rate of sepsis in our patients is undetermined because stone analysis information was not available.

\section{Conclusion}

Despite these limitations of our study, acceptable rates were determined in terms of treatment success and complications of PNL with multiple single step dilatation technique applied for staghorn stones. In this regard, prospective studies with largescale series are needed to reach definitive conclusions.

\section{Ethics}

Ethics Committee Approval: Retrospective study.

Informed Consent: Written informed consent was obtained from the patients.

Peer-review: Externally peer-reviewed.

\section{Authorship Contributions}

Surgical and Medical Practices: C.S.I., Concept: Y.Ö.I., Design: C.S.i., Data Collection or Processing: C.S.I., Analysis or 
Interpretation: Y.ö.I., Literature Search: C.S.I., Writing: C.S.I., Y.ö.i.

Conflict of Interest: No conflict of interest was declared by the authors.

Financial Disclosure: The authors declared that this study received no financial support.

\section{References}

1. Türk C, Knoll T, Petrik A, Sarica K, Skolarikos A, Straub M, Seitz C; Guidelines Associates: Dabestani S, Drake T, Grivas N, Ruhayel Y, Tepeler AK. EAU Guidelines on Urolithiasis. European Association of Urology; 2016.

2. Travis DG, Tan HL, Webb DR. Single increment dilation for percutaneous renal surgery: an experimental study. Br J Urol 1991;68:144-147.

3. Suelozgen T, Isoglu CS, Turk H, Yoldas M, Karabicak M, Ergani B, Boyacioglu H, Ilbey YO. Can We Use Single-step Dilation as a Safe Alternative Dilation Method in Percutaneous Nephrolithotomy? Urology 2017;99:38-41.

4. Altunrende F, Tefekli A, Stein RJ, Autorino R, Yuruk E, Laydner H, Binbay $M$, Muslumanoglu AY. Clinically insignificant residual fragments after percutaneous nephrolithotomy: medium-term follow-up. J Endourol $2011 ; 25: 941-945$
5. Wickham JE, Kellet MJ. Percutaneous nephrolithotomy. Br Med J (Clin Res Ed) 1981;12:1571-1572.

6. Amjadi M, Zolfaghari A, Elahian A, Tavoosi A. Percutaneous nephrolithotomy in patients with previous open nephrolithotomy: one shot versus telescopic technique for tract dilatation. J Endourol 2008;22:423-425.

7. de la Rosette J, Assimos D, Desai M, Gutierrez J, Lingeman J, Scarpa R, Tefekli A; CROES PCNL Study Group. The Clinical Research Office of the Endourological Society Percutaneous Nephrolithotomy Global Study: indications, complications, and outcomes in 5803 patients. J Endourol 2011;25:11-17.

8. El-Nahas AR, Shokeir AA, El-Assmy AM, Mohsen T, Shoma AM, Eraky I, ElKenawy MR, El-Kappany HA. Post-percutaneous nephrolithotomy extensive hemorrhage: a study of risk factors. J Urol 2007;177:576-579.

9. Tefekli A, Ali Karadag M, Tepeler K, Sari E, Berberoglu Y, Baykal M, Sarilar 0 , Muslumanoglu AY. Classification of percutaneous nephrolithotomy complications using the modified Clavien grading system: looking for a standard. Eur Urol 2008:53:184-190.

10. Kyriazis I, Panagopoulos $V$, Kallidonis $P$, Özsoy $M$, Vasilas $M$, Liatsikos E. Complications in percutaneous nephrolithotomy. World J Urol 2015;33:1069-1077.

11. Amirhassani S, Mousavi-Bahar SH, Iloon Kashkouli A, Torabian S. Comparison of the safety and efficacy of one shot and telescopic metal dilatation in percutaneous nephrolithotomy: a randomized controlled trial. Urolithiasis 2014;42:269-273. 